\title{
Frontiers in Climate Smart Food Systems: Outlining the Research Space
}

\author{
Stephen Whitfield ${ }^{1 *}$, Andrew Juan Challinor ${ }^{2,3}$ and Robert M. Rees ${ }^{4}$ \\ ${ }^{1}$ School of Earth and Environment, Sustainability Research Institute, University of Leeds, Leeds, United Kingdom, ${ }^{2}$ School of \\ Earth and Environment, Institute for Climate and Atmospheric Science, University of Leeds, Leeds, United Kingdom, ${ }^{3}$ CGIAR \\ Research Program on Climate Change, Agriculture and Food Security (CCAFS), Cali, Colombia, ${ }^{4}$ Carbon Management \\ Centre, Scotland's Rural College, Edinburgh, United Kingdom
}

Keywords: climate-smart agriculture, food security, systems thinking, sustainable development goals, cross-disciplinary

Food systems, from the local to the global, face a complex set of challenges in the twenty-first century. As recognized in the latest round of the United National Framework Convention on Climate Change talks, it is clear that global targets for mitigating greenhouse gas emissions cannot be met without major alterations to agriculture and supply chains. At the same time, these systems must adapt to changing and uncertain climatic conditions. Across national and international agendas, agriculture plays a further central role in achieving food security, driving economic growth, alleviating poverty, and sustaining ecological functions and services. In reality, food and agriculture intersect with every one of the UN sustainable development goals (SDGs), underlining growing global concern for, sometimes highly contested debate over, sustainability in food systems.

It is in food systems, perhaps more than anywhere else, that we have the clearest illustrations of the contemporary realities of climate change. If evidence were needed that the challenges of a changing climate are not just those of the future, but of today, then, recent food price shocks, crop failures, and famine crises should suffice (FSIN, 2017). These events are not, of course, determined by weather alone, but are the manifestation of complex and cross-scale social, political, economic, and ecological processes, and should serve as a warning against simple and deterministic interpretations of contemporary food systems. Grappling with these complex issues is essential, if we are to understand how climate change contributes toward risks to the food system, thereby enabling targeted coordination of policies within and across governments.

In this short paper, we briefly discuss the burgeoning approach of climate-smart agriculture, which seeks to integrate complex issues and set out a direction for change in contemporary systems. Only broad systemic perspectives, as advocated and advanced in this journal section, positions us (as a broad and diverse academic community) to engage with the grand challenges of providing healthy diets for a growing population, avoiding unsustainable land use change, and adapting to and mitigating climate change. The primary aim of this piece is, therefore, to set out our call for journal contributions from interdisciplinary, cross-scalar, and systemic approaches to the goal of designing climate-smart food systems. We argue here that these designs include and necessarily transcend climate-smart agriculture.

Received: 12 December 2017

Accepted: 22 January 2018

Published: 31 January 2018

Citation:

Whitfield S, Challinor AJ and Rees RM (2018) Frontiers in Climate Smart Food Systems: Outlining the Research Space. Front. Sustain. Food Syst. 2:2. doi: 10.3389/fsufs.2018.00002

\section{THE CONTEXT: FOOD SECURITY, CLIMATE CHANGE, AND THE SDGs}

Feeding the human population sustainably has become an increasing challenge as global populations grow and resources remain finite. Much-cited projections have suggested that the global population will reach 9.6 billion by 2050 (UNDESA, 2013), and this has been the basis for claims that food production must increase by $70 \%$ globally and by $100 \%$ in low-income countries (compared with 
2000 levels) in response (Godfray et al., 2010; FAO, 2011). These are targets which, for most crops in most regions, we are falling short of on current projections (Ray et al., 2013). While this seemingly justifies investment in crop improvements and intensification, such techno-centric narratives should be accepted with caution (Tomlinson, 2013). Meeting the SDGs for food security means not only producing more food but also addressing both under- and over-consumption. Chronic undernourishment and micro nutrient deficiencies affect over 800 million people, predominantly in low-income countries (FAO, 2017), while obesity and dietary-related disease (type II diabetes and coronary heart disease) are on the increase almost universally (World Health Organization, 2009; FAO, 2017). Meeting SDGs, therefore, means not only tackling food availability but also developing new solutions and approaches to addressing unequal distribution and access to food, changing dietary trends (Tilman and Clark, 2014) and enabling people to utilize food in safe and nutritious ways.

The challenges posed by climate change are as multifaceted as those facing food systems. Climate change is broadly expected to further constrain productivity in the tropics (i.e., those regions where low income countries are predominantly located) (Challinor et al., 2014). It has long been known that increasing climatic variability across space and time, the shifting of rainfall and temperature patterns and increasing frequency of climatic extremes pose challenges for food production. While the yieldenhancing effect of $\mathrm{CO}_{2}$ fertilization might be one cause for optimism, this effect interacts with temperature, water, nitrogen, and ozone in ways that are not fully predictable; and, further, $\mathrm{CO}_{2}$ is likely to increase the distribution and competitiveness invasive weeds (Porter et al., 2014). Climate projections are associated with noisy signals and, in many cases, uncertainty. Even the pathways by which climate impacts materialize are not yet fully understood, in part because of the complex nature of transboundary climate risk within and beyond food systems (Challinor et al., 2017a). Such uncertain and unstable weather patterns justify a focus on building resilience in our food production and supply chains, but such attempts must look beyond narrowly conceived metrics of productivity, and engage with questions of efficiency, diversity, communication, and governance.

Agriculture, forestry, and land use contribute up to $25 \%$ of global anthropogenic greenhouse gas emissions (Smith et al., 2014) with additional emissions in the food sector coming from processing and distribution. Livestock production accounts for a particularly large proportion of these emissions [14.5\% of global emissions (Ripple et al., 2014)] and has, therefore, become a particular focus for mitigation (Smith et al., 2008). Political will and recognition of the need to address the footprint of agriculture has grown with the signing of the Paris Agreement in 2016. Limiting warming to 2 or $1.5^{\circ} \mathrm{C}$ means not only increasing productivity and increasing resilience without increasing emissions; but that emissions must actually fall, and by significant amounts (Peters et al., 2013; Millar et al., 2017). A recent analysis by Wollenberg et al. (2016) suggests that plausible agricultural development pathways are likely to deliver only $21-40 \%$ of the mitigation demanded by the Paris agreement to limit global temperature rises to $2^{\circ} \mathrm{C}$. Novel thinking and new technologies and techniques alongside returns to traditional/extensive systems that draw on local ecological knowledge will need urgently to be developed within a supportive policy framework if we are to achieve the changes required.

Despite the urgency of the climate-smart agenda, we must be careful not to reduce the priorities of the agriculture and food system to providing food and reducing emissions. Nor is climate change the only context in which food systems operates. The food system must contribute to broader SDGs such that societal needs are met and environmental limits avoided at scales that range from the global to the individual household; contributing to achieving gender equality, improving health, sustainable use and access to water, meeting energy needs, and conserving biodiversity, and more.

The market, investment, and political contexts that shape our agriculture and food systems present both opportunities and barriers to a transition to climate-smart food systems. The global shift toward food supply chains that are centralized around large supermarkets and the uneven liberalization of markets through removal of tariffs is creating a competitive market and fluctuating farm-gate commodity prices that disadvantage the small-scale resource constrained producer (Hazell et al., 2010). Reduced state budgets for investment in agricultural innovation have seen a growing role for the private sector in international agricultural development, with an associated shift in emphasis toward research and development of impact-at-scale and state-of-the-art agro-technologies and, in some contexts, a loss of extension services (Sumberg and Thompson, 2012; Brooks, 2015). Moreover, land constraints, driven by population growth and limits to the expansion of agricultural land globally, are compounded in some contexts by large international land acquisitions (land grabs) and inequalities in rights and access to land (Borras and Franco, 2012).

\section{SUSTAINABLE INTENSIFICATION, CSA, AND THE EVOLUTION OF CONCEPTS}

In agriculture, as elsewhere, popular discourse has a limited shelf-life, as a combination of critique and theoretical evolution drive us to adopt new terminology to describe our ambitions and visions for agricultural development. The language of "green revolution" of the 1960s and 1970s, through the participatory and environmental movements of the 1980s and 1990s, came to be associated with negative ecological consequences (Pingali and Rosegrant, 1994), and as attention turned to seeing production growth in Africa a new discourse of "sustainable intensification" became popularized in the 1990s (Pretty et al., 2011). Perhaps reflecting the growing prominence of climate change within environmental agendas, as well as need for attention to be paid to the adaptive capacities within agricultural production to environmental change, the paradigm of "climate smart agriculture" (brought into popular use by the UN FAO in 2010) has become the well-established usurper of its predecessors. Climate smart agriculture is defined as an approach that simultaneously focuses on, or achieves, increases in agricultural yields, improved resilience or adaptation to climatic changes and variability, and reductions in agricultural greenhouse gas emissions (Lal et al., 2011; Lipper et al., 2014). These three pillars of climate-smart agriculture are 
now well established and have driven major research agendas including that of the CGIAR. ${ }^{1}$

In application, climate smart agriculture tends to place emphasis on new technologies and techniques, such as improved seed varieties, conservation agriculture, alternate wetting and drying rice production, precision fertilizer, etc., all of which have histories that long precede the adoption of the CSA label. Notably, these technologies do not fit exclusively to one or other end of the extensification-intensification spectrum, and in many cases are platforms or suites of practice, which (at least, at a rhetorical level) are to be adapted to context rather than universally prescribed. It is important to note too that CSA, as described and advocated by the FAO and the CGIAR represents an agenda that is not limited to agricultural technologies, but includes climate services, cooperative governance structures, data processing, and information/education. Such broad conceptualizations of CSA come in for both praise and criticism; a persistent tension between the value of holistic, non-prescriptive approach, and the dangers of catch-all buzz-word that is used to capture investment and justify questionable agendas, e.g., of international donors or agri-tech multinationals.

Because, under CSA, combinations of practice are coupled with combinations of objectives, and because of the diverse agro-ecological conditions under which complex technologies are advocated and applied, the scope for research and evidencebuilding is limitless. Conservation agriculture is a good case in point. Extensive literature on controlled trials of yields, soil properties, pests, under different management, water regimes, soils, and more [for example, see Thierfelder et al. (2015), for a recent review of studies on conservation agriculture in southern Africa] and on-farm studies of burdens on labor, resources, household capitals [for example, see Andersson and D'souza (2014) for a review of socioeconomic studies of conservation agriculutre adoption] have all contributed to, but far from resolved, questions about what forms of conservation agriculture work, for whom, and under what circumstances. Moreover, in evaluating CSA, we often lack clear metrics of success: can a yield increase that contributes little to greenhouse gas mitigation, or an overall emissions reduction that reduces water use efficiency be considered "climate smart"? Should we give more weight to one priority over the others? Perhaps inevitably, the evidence base for CSA technologies has lagged behind their promotion and advocacy, sometimes resulting in unmet expectations and criticisms of the CSA concept (Whitfield, 2015; Newell and Taylor, 2018).

\section{BEYOND CSA: TRADE-OFFS AND SUSTAINABILITY IN AGRICULTURE AND FOOD}

There is of course a potential mismatch between the complex context and multifaceted priorities for agriculture and food systems set out at the beginning of this paper and the three-pillar winwin-win language of climate smart agriculture. Some authors have recognized the tendency in adopting CSA language to also adopt

${ }^{1}$ e.g., https://ccafs.cgiar.org/climate-smart-agriculture. a concept of sustainability that is too narrow; in which issues of water, biodiversity, social equity, livelihoods become peripheral (Neufeldt et al., 2013), with the potential that trade-offs in these "extra" dimensions become overlooked (Whitfield et al., 2015a). This is particularly the case when the test bed of our climate smart agriculture is limited to the controlled field trial, void of the societal, economic, and broader ecological conditions within which farmers operate, prioritize, and make decisions.

In research, a CSA lens may risk focusing our attention on the field rather than on the cross scale food system, it may cause us to miss the environmental and social trade-offs of agricultural change that are non-climatic and in doing so might lead to inappropriate solutions or even to missed opportunities for sustainable development within our food systems. Impressive narratives of yield benefits, soil improvements, or water efficiencies might drive agendas of scaling-up technologies and the setting of ambitious adoption targets, but mask a multiplicity of context or system specific costs, trade-offs, or risks (Wesselink et al., 2015; Campbell et al., 2016).

In direct response to such concerns, we have begun to see the emergence of what is arguably the next discursive wave: discussions of climate-smart landscapes, to draw attention to integrated landscape managements and functions (Scherr et al., 2012); nutrition- and climate-smart agriculture, to draw attention to nutrition as a fourth key priority or pillar (Beuchelt and Badstue, 2013); and climate smart food systems, to draw attention to the dynamic interconnections across food production, supply, and consumption and particularly the role of diets in driving agricultural production (Vermeulen et al., 2015). It is the latter of these that, because of its broader systemic focus and we adopt as an umbrella concept for this new journal section.

\section{THE IMPORTANCE OF SYSTEMS APPROACHES}

A growing body of systems research-"farming systems research" (Collinson, 2000; Darnhofer et al., 2012); agri-food systems (Thompson and Scoones, 2009); socio-ecological systems (Folke, 2006; Young et al., 2006; Lambin and Meyfroidt, 2010); innovation systems (Freeman, 1995; Geels, 2004); earth and climate systems (IPCC, 2007) - focuses on understanding and modeling the complex processes, thresholds, and feedbacks that define real-world systems, in increasingly cross-disciplinary ways. There is good reason for the resurgence of systems thinking within agriculture and food policy and research (Thompson and Scoones, 2009). In addressing the urgent need to build resilient, sustainable, and just food systems capable of feeding a growing population, a systems approach calls on us to think, for example, about the globally interlinked nature of local production, consumption, and waste (e.g., through markets and trade); the dependency and impacts of food provision on changing ecological and climatic systems and services; and the role and movement of knowledge, information, and values across nodes of decision making at a variety of scales (Darnhofer et al., 2012; Whitfield et al., 2015b). Some of these systems link the local to the global (e.g., where agriculture is considered as playing a key role in climate change mitigation), 
individuals to market forces and regulations, and current activities to future impacts.

Of course, scale is important. The inherent cross scale and multisited nature of food systems presents methodological challenges and justifies methodological innovation. Systems research has become widely associated with the tools of quantitative modeling (Challinor et al., 2007; Thornton et al., 2011), which offers an increasingly sophisticated means of capturing and simulating system dynamics and exploring scenarios of change. Models can have a useful role in scaling out observations and principles across space and time, but efforts at doing so must always be mediated by questions of appropriate complexity and uncertainty (Challinor et al., 2017b).

Building resilient, just, and sustainable food systems requires that we also understand those interactions and dynamics that are less readily modeled: the ways in which changes in agricultural practices are shaped through social interactions and learning (Whitfield, 2015); the innovative ways in which people adapt within changing environments (Thomas et al., 2007; Reij and Waters-Bayer, 2014); the multifaceted value systems and priorities of individual producers and consumers (Lusk and Briggeman, 2009); and more.

Clearly, addressing cross-system and multi-scale synergies and trade-offs must involve multiple disciplines interacting in iterative ways. Trial-station agronomy and soil science, landscape ecological and hydrological studies, and studies of production, livelihoods, trade, and consumption from the social sciences, humanities, health and nutrition science, economics and business studies, can all offer important insight into the complex and place-dependent realities of agriculture and food systems. Climate and climate impacts models, and the coupling of market, hydrology, ecology, and other models can help us to investigate processes across contexts and scales. In doing so, those place- based and model-based studies alike have much to gain from the insight and data that are offered by the other. This, all, potentially contributes to an evidence base with application for, but also that must be considered critically in the context of, decision-making and political contexts.

\section{SETTING OUT A RESEARCH AGENDA}

We argue that climate-smart food systems research, in drawing together multiple disciplines, should be centered around, and

\section{REFERENCES}

Andersson, J. A., and D'souza, S. (2014). From adoption claims to understanding farmers and contexts: a literature review of Conservation Agriculture (CA) adoption among smallholder farmers in southern Africa. Agric. Ecosyst. Environ. 187, 116-132. doi:10.1016/j.agee.2013.08.008

Beuchelt, T. D., and Badstue, L. (2013). Gender, nutrition-and climate-smart food production: opportunities and trade-offs. Food Secur. 5, 709-721. doi:10.1007/ s12571-013-0290-8

Borras, S. Jr., and Franco, J. (2012). Global land grabbing and trajectories of agrarian change: a preliminary analysis. J. Agrar. Chang. 12, 34-59. doi:10.1111/ j.1471-0366.2011.00339.x

Brooks, S. (2015). "Philanthrocapitalism, 'pro-poor' agricultural biotechnology and development," in New Philanthropy and Social Justice: Debating the Conceptual and Policy Discourse, ed. B. Morvaridi (Chicago: Policy Press), 101-116.

Campbell, B. M., Vermeulen, S. J., Aggarwal, P. K., Corner-Dolloff, C., Girvetz, E., Loboguerrero, A. M., et al. (2016). Reducing risks to food security from climate change. Glob. Food Secur. 11, 34-43. doi:10.1016/j.gfs.2016.06.002 be at the service of, key questions and challenges for our food systems. It is problem-based inter- and multidisciplinarity, not discipline-centered collaboration that solves this sort of challenge (Robinson, 2008). Reflecting the discussion laid out above, the questions that will be at the core of the Climate Smart Food Systems section of Frontiers in Sustainable Food Systems include:

- What is climate smartness and how do we measure it?

- What are the social and economic impacts of climate smart agriculture?

- What trade-offs emerge from climate-smart practices, and at what levels do we consider trade-offs to be safe and just?

- How do theory-based climate-smart actions differ across spatial scale? What are the theoretical and practical feasibility and consequences of scaling up actions within and across systems?

- Which climate-smart actions are feasible? In which systems and at which scales is climate smartness evident?

- How can diet choices contribute to the climate smartness of the food system in the long term?

Tackling these questions will not be easy and as researchers we should not shy away from attempts to innovate or venture outside of our disciplines, nor should we be put off by the prospect that such attempts might fail or expose ourselves to uncomfortable debate. The question of how to achieve climate smart food systems has no simple answers. This journal itself should, we believe, become a space for the furthering of considered and challenging academic conversation.

\section{AUTHOR CONTRIBUTIONS}

All authors contributed ideas and text. SW prepared manuscript. All authors edited the manuscript.

\section{FUNDING}

This study was funded by the UK Research and Innovation as part of the Global Challenges Research Fund, BB/P027784/1 to SW.

Challinor, A., Wheeler, T., Garforth, C., Craufurd, P., and Kassam, A. (2007). Assessing the vulnerability of food crop systems in Africa to climate change. Clim. Chang. 83, 381-399. doi:10.1007/s10584-007-9249-0

Challinor, A. J., Adger, W. N., and Benton, T. G. (2017a). Climate risks across borders and scales. Nat. Clim. Chang. 7, 621-623. doi:10.1038/ nclimate3380

Challinor, A. J., Müller, C., Asseng, S., Deva, C., Nicklin, K. J., Wallach, D., et al. (2017b). Improving the use of crop models for risk assessment and climate change adaptation. Agric. Syst. 159, 296-306. doi:10.1016/j.agsy. 2017.07.010

Challinor, A. J., Watson, J., Lobell, D. B., Howden, S. M., Smith, D. R., and Chhetri, N. (2014). A meta-analysis of crop yield under climate change and adaptation. Nat. Clim. Change 4, 287-291. doi:10.1038/nclimate2153

Collinson, M. P. (2000). A History of Farming Systems Research. Oxford: Cabi Press.

Darnhofer, I., Gibbon, D., and Dedieu, B. (2012). Farming Systems Research: an Approach to Inquiry. London: Springer.

FAO. (2011). The State of the World's Land and Water Resources for Food and Agriculture. London: Food and Agriculture Organization of the United Nations.

FAO. (2017). The State of Food Security and Nutrition in the World 2017. Building Resilience for Peace and Food Security. Rome: IFAD, FAO, UNICEF, WFP, and WHO.

Folke, C. (2006). Resilience: the emergence of a perspective for social-ecological systems analyses. Glob. Environ. Chang. 16, 253-267. doi:10.1016/j.gloenvcha. 2006.04.002 
Freeman, C. (1995). The 'National System of Innovation' in historical perspective. Cambridge J. Econ. 19, 5-24.

FSIN. (2017). Global Report on Food Crises 2017. Food Security Information Network. Available at: http://documents.wfp.org

Geels, F. W. (2004). From sectoral systems of innovation to socio-technical systems: insights about dynamics and change from sociology and institutional theory. Res. policy 33, 897-920. doi:10.1016/j.respol.2004.01.015

Godfray, H. C. J., Beddington, J. R., Crute, I. R., Haddad, L., Lawrence, D., Muir, J. F., et al. (2010). Food security: the challenge of feeding 9 billion people. Science 327, 812-818. doi:10.1126/science.1185383

Hazell, P., Poulton, C., Wiggins, S., and Dorward, A. (2010). The future of small farms: trajectories and policy priorities. World Dev. 38, 1349-1361. doi:10.1016/j.worlddev.2009.06.012

IPCC. (2007). Climate Change 2007: Synthesis Report. Contribution of Working Groups I, II and III to the Fourth Assessment Report of the Intergovernmental Panel on Climate Change, eds Core Writing Team, R. K. Pachauri, and A. Reisinger (Geneva, Switzerland: IPCC).

Lal, R., Delgado, J., Groffman, P., Millar, N., Dell, C., and Rotz, A. (2011). Management to mitigate and adapt to climate change. J. Soil Water Conserv. 66, 276-285. doi:10.2489/jswc.66.4.276

Lambin, E. F., and Meyfroidt, P. (2010). Land use transitions: socio-ecological feedback versus socio-economic change. Land use policy 27, 108-118. doi:10.1016/ j.landusepol.2009.09.003

Lipper, L., Thornton, P., Campbell, B. M., Baedeker, T., Braimoh, A., Bwalya, M., et al. (2014). Climate-smart agriculture for food security. Nat. Clim. Chang. 4, 1068-1072. doi:10.1038/nclimate2437

Lusk, J. L., and Briggeman, B. C. (2009). Food values. Am. J. Agric. Econ. 91, 184-196. doi:10.1111/j.1467-8276.2008.01175.x

Millar, R. J., Fuglestvedt, J. S., Friedlingstein, P., Rogelj, J., Grubb, M. J., Matthews, H. D., et al. (2017). Emission budgets and pathways consistent with limiting warming to 1.5 C. Nat. Geosci. 10, 741. doi:10.1038/ngeo3031

Neufeldt, H., Jahn, M., Campbell, B. M., Beddington, J. R., Declerck, F., De Pinto, A., et al. (2013). Beyond climate-smart agriculture: toward safe operating spaces for global food systems. Agric. Food Secur. 2, 12. doi:10.1186/2048-7010-2-12

Newell, P., and Taylor, O. (2018). Contested landscapes: the global political economy of climate-smart agriculture. J. Peasant Stud. 45, 108-129. doi:10.1080/ 03066150.2017 .1324426

Peters, G. P., Andrew, R. M., Boden, T., Canadell, J. G., Ciais, P., Le Quéré, C., et al. (2013). The challenge to keep global warming below 2 C. Nat. Clim. Chang. 3, 4-6. doi:10.1038/nclimate 1783

Pingali, P. L., and Rosegrant, M. W. (1994). Confronting the environmental consequences of the Green Revolution in Asia. Washington, DC: International Food Policy Research Institute (IFPRI).

Porter, J. R., Xie, L., Challinor, A. J., Cochrane, K., Howden, S. M., Iqbal, M. M., et al. (2014). "Food security and food production systems," in Climate Change 2014: Impacts, Adaptation, and Vulnerability. Part A: Global and Sectoral Aspects. Contribution of Working Group II to the Fifth Assessment Report of the Intergovernmental Panel of Climate Change, eds C. B. Field, V. R. Barros, D. J. Dokken, K. J. Mach, M. D. Mastrandrea, T. E. Bilir, M. Chatterjee, K. L. Ebi, Y. O. Estrada, R. C. Genova, B. Girma, E. S. Kissel, A. N. Levy, S. Maccracken, P. R. Mastrandrea, and L. L. White (Cambridge, United Kingdom and New York, NY, USA: Cambridge University Press), XXX-YYY.

Pretty, J., Toulmin, C., and Williams, S. (2011). Sustainable intensification in African agriculture. Int. J. Agric. Sustainability 9, 5-24. doi:10.3763/ijas.2010.0583

Ray, D. K., Mueller, N. D., West, P. C., and Foley, J. A. (2013). Yield trends are insufficient to double global crop production by 2050. PLoS ONE 8:e66428. doi:10.1371/journal.pone.0066428

Reij, C., and Waters-Bayer, A. (2014). Farmer Innovation in Africa: a Source of Inspiration for Agricultural Development. London: Routledge.

Ripple, W. J., Smith, P., Haberl, H., Montzka, S. A., Mcalpine, C., and Boucher, D. H. (2014). Ruminants, climate change and climate policy. Nat. Clim. Chang. 4, 2-5. doi:10.1038/nclimate2081

Robinson, J. (2008). Being undisciplined: transgressions and intersections in academia and beyond. Futures 40, 70-86. doi:10.1016/j.futures.2007.06.007

Scherr, S. J., Shames, S., and Friedman, R. (2012). From climate-smart agriculture to climate-smart landscapes. Agric. Food Secur. 1, 12. doi:10.1186/20487010-1-12
Smith, P., Clark, H., Dong, H., Elsiddig, E., Haberl, H., Harper, R., et al. (2014). "Agriculture, forestry and other land use (AFOLU)," in Climate Change 2014: Mitigation of Climate Change. Contribution of Working Group III to the Fifth Assessment Report of the Intergovernmental Panel on Climate Change, eds O. Edenhofer, R. Pichs-Madruga, Y. Sokona, E. Farahani, S. Kadner, K. Seyboth, et al. (Cambridge, UK: Cambridge University Press), 811-922.

Smith, P., Martino, D., Cai, Z., Gwary, D., Janzen, H., Kumar, P., et al. (2008). Greenhouse gas mitigation in agriculture. Philos. Trans. R. Soc. A 363, 789-813. doi:10.1098/rstb.2007.2184

Sumberg, J., and Thompson, J. (2012). Contested Agronomy: Agricultural Research in a Changing World. London: Routledge.

Thierfelder, C., Rusinamhodzi, L., Ngwira, A. R., Mupangwa, W., Nyagumbo, I., Kassie, G. T., et al. (2015). Conservation agriculture in Southern Africa: advances in knowledge. Renew. Agr. Food Syst. 30, 328-348. doi:10.1017/ S1742170513000550

Thomas, D. S., Twyman, C., Osbahr, H., and Hewitson, B. (2007). Adaptation to climate change and variability: farmer responses to intra-seasonal precipitation trends in South Africa. Clim. Change 83, 301-322. doi:10.1007/s10584-006-9205-4

Thompson, J., and Scoones, I. (2009). Addressing the dynamics of agri-food systems: an emerging agenda for social science research. Environ. Sci. Policy 12, 386-397. doi:10.1016/j.envsci.2009.03.001

Thornton, P. K., Jones, P. G., Ericksen, P. J., and Challinor, A. J. (2011). Agriculture and food systems in sub-Saharan Africa in a $4 \mathrm{C}+$ world. Philos. Trans. R. Soc. A 369, 117-136. doi:10.1098/rsta.2010.0246

Tilman, D., and Clark, M. (2014). Global diets link environmental sustainability and human health. Nature 515, 518-522. doi:10.1038/nature13959

Tomlinson, I. (2013). Doubling food production to feed the 9 billion: a critical perspective on a key discourse of food security in the UK. J. Rural Stud. 29, 81-90. doi:10.1016/j.jurstud.2011.09.001

UNDESA. (2013). World population prospects: the 2012 revision. Working Paper No ESA/P/WP.228 United Nations Department of Economic and Social Affairs. Available at: esa.un.org

Vermeulen, S. J., Porter, J. R., and Bennetzen, E. (2015). "Climate-smart food systems: plenary presentation," in Presentation at the Climate Smart Agriculture Global Science Conference 16-18 March 2015, Montpellier.

Wesselink, A., Challinor, A. J., Watson, J., Beven, K., Allen, I., Hanlon, H., et al. (2015). Equipped to deal with uncertainty in climate and impacts predictions: lessons from internal peer review. Clim. Change 132, 1-14. doi:10.1007/ s10584-014-1213-1

Whitfield, S. (2015). Adapting to Climate Uncertainty in African Agriculture: Narratives and Knowledge Politics. London: Routledge.

Whitfield, S., Benton, T. G., Dallimer, M., Firbank, L. G., Poppy, G. M., Sallu, S. M., et al. (2015a). Sustainability spaces for complex agri-food systems. Food Secur. 7, 1291-1297. doi:10.1007/s12571-015-0512-3

Whitfield, S., Dixon, J. L., Mulenga, B. P., and Ngoma, H. (2015b). Conceptualising farming systems for agricultural development research: cases from Eastern and Southern Africa. Agric. Syst. 133, 54-62. doi:10.1016/j.agsy.2014.09.005

Wollenberg, E., Richards, M., Smith, P., Havlík, P., Obersteiner, M., Tubiello, F. N., et al. (2016). Reducing emissions from agriculture to meet the $2 \mathrm{C}$ target. Glob. Chang. Biol. 22, 3859-3864. doi:10.1111/gcb.13340

World Health Organization. (2009). Global Health Risks: Mortality and Burden of Disease Attributable to Selected Major Risks. Geneva: World Health Organization.

Young, O. R., Berkhout, F., Gallopin, G. C., Janssen, M. A., Ostrom, E., and Van Der Leeuw, S. (2006). The globalization of socio-ecological systems: an agenda for scientific research. Global Environ. Chang. 16, 304-316. doi:10.1016/ j.gloenvcha.2006.03.004

Conflict of Interest Statement: The authors declare that the research was conducted in the absence of any commercial or financial relationships that could be construed as a potential conflict of interest.

Copyright () 2018 Whitfield, Challinor and Rees. This is an open-access article distributed under the terms of the Creative Commons Attribution License (CC $B Y$ ). The use, distribution or reproduction in other forums is permitted, provided the original author(s) and the copyright owner are credited and that the original publication in this journal is cited, in accordance with accepted academic practice. No use, distribution or reproduction is permitted which does not comply with these terms. 